Research, part of a Special Feature on The influence of human demography and agriculture on natural systems in the Neotropics

\title{
Land-Use and Land Cover Dynamics in South American Temperate Grasslands
}

\author{
$\underline{\text { Germán Baldi }}^{1,2}$ and $\underline{\text { José M. Paruelo }}^{1,2}$
}

\begin{abstract}
In the Río de la Plata grasslands (RPG) biogeographical region of South America, agricultural activities have undergone important changes during the last 15-18 years because of technological improvements and new national and international market conditions. We characterized changes in the landscape structure between 1985-1989 and 2002-2004 for eight pilot areas distributed across the main regional environmental gradients. These areas incorporated approximately $35 \%$ of the $7.5 \times 10^{5} \mathrm{~km} \& \# 178$ of the system. Our approach involved the generation of land-use and land cover maps, the analysis of landscape metrics, and the computation of annual transition probabilities between land cover types. All of the information was summarized in 3383 cells of $8 \times 8 \mathrm{~km}$. The area covered by grassland decreased from 67.4 to $61.4 \%$ between the study periods. This decrease was associated with an increase in the area of annual crops, mainly soybean, sunflower, wheat, and maize. In some subunits of the RPG, i.e., Flat Inland Pampa, the grassland-to-cropland transition probability was high $\left(p_{\mathrm{G}} \rightarrow \mathrm{C}=3.7 \times 10^{-2}\right)$, whereas in others, i.e., Flooding Pampa, this transition probability was low $\left(p_{\mathrm{G}} \rightarrow \mathrm{C}=6.7 \times 10^{-3}\right)$. Our description of the magnitude, direction, and spatial distribution of land-use and land cover changes provides a basis from which to develop spatially explicit scenarios of land cover change.
\end{abstract}

Key Words: campos; fragmentation; grasslands; land use; landscape dynamics, pampas; remote sensing; spatial metrics

\section{INTRODUCTION}

Human activities are changing land ecosystems at unprecedented rates: in the last 40 years, natural vegetation has been cleared at $4 \times 10^{6} \mathrm{ha} / \mathrm{yr}$ for agricultural activities (Tilman et al. 2001). Together, croplands and rangelands now constitute approximately $40 \%$ of the ice-free terrestrial surface (Ramankutty and Foley 1999). Development trends have created large divergences in the land cover patterns of the mid-latitudes. Many developed countries have experienced an expansion of native vegetation over formerly cultivated land (Grau et al. 2003, Kauppi et al. 2006), whereas most developing countries have undergone the fastest expansion and intensification of cultivation in their history (Ramankutty et al. 2002).

Changes in land use and land cover represent a complex environmental, socioeconomic, and technological problem. On the one hand, agriculture is essential to human subsistence because it provides food, fibers, fuels, and construction materials and globally enhances economic development and human welfare (Millennium Ecosystem Assessment 2005). On the other hand, agricultural activities generate cascading impacts that modify the fluxes of energy and materials, the structure and functioning of natural ecosystems, and the supply of goods and services, affecting human well-being (Ehrlich and Ehrlich 1992, Vitousek 1994, Foley et al. 2005).

The effect of land cover change on the supply of ecosystem services derives not only from a reduction in the area of the original cover, but also from a transformation of the landscape structure. The spatial distribution of different land cover patches modifies the land-atmosphere interaction (Pielke and Avissar 1990) and hence, the exchange of water, energy, and materials (Naef et al. 2002, Nosetto et al. 2005). The landscape configuration 
affects the horizontal redistribution of materials between patches and the magnitude of outputs (Saunders et al. 1991). The spatial distribution of different patches also affects the abundance and persistence of local plant and animal populations because it determines factors such as metapoluation dynamics, dispersal routes, and carrying capacity (Fahrig and Merriam 1994, Galetto et al. 2007). The development of land-use policies that are oriented to guarantee food security and the provision of both market goods and ecosystem services requires as basic input the assessment of landscape structure and dynamics.

One of the most human-modified biomes of the world is grassland (Hannah et al. 1995). In temperate southern South America, the extensive plains named Río de la Plata Grasslands (RPG) have been transformed into cropland at high rates since the beginning of the 20th century; in Argentina, < $10 \%$ of the RPG area was cropland in the 1880 s, whereas $>20 \%$ of half of the area was cropland in the 1930s (Vervoorst 1967, Soriano 1991, Hall et al. 1992, Viglizzo et al. 2001). The RPG play a key role in international food security through the growing export of agricultural goods. In the last two decades (1990s and 2000s), the rate of agricultural expansion increased considerably because of technological factors, e.g., nontillage techniques and genetically modified crops, and market conditions, i.e., the increase in the demand for soybean by Asian countries and monetary exchange policies (Alexandratos 1999, Secretaría de Agricultura, Ganadería, Pesca, y Alimentos 2002, 2004, Dirección de Estadísticas AgropecuariasMinisterio de Ganadería, Agricultura, y Pesca 2003c, Paruelo et al. 2005). Agricultural intensification and expansion to monocultures of soybean, sunflower, maize, wheat, and rice, as well as pine and eucalyptus, compromise the long-term sustainability of the region and the provision of vital ecosystem services such as carbon sequestration, soil preservation, and regional climate amelioration (Sala and Paruelo 1997, Viglizzo et al. 1997). The speed of current changes and the complexity of their biophysical and human drivers and impacts require a flexible and well-founded body of knowledge to support land-use planning at multiple spatial (individual farm to basin) and temporal (season to decades) scales. Despite this, and paradoxically, local governments and nongovernmental organizations lack the basic information of an objective estimation of the land surface under different land-use types and their spatial distribution (Paruelo et al. 2004).
Our objectives were: to characterize the land cover and land use in the RPG in the periods of 1985-1989 and 2002-2004; to evaluate grassland fragmentation in these periods; and to quantify the probabilities of transition between land-use and land cover classes.

\section{METHODS}

\section{Study area}

The Río de la Plata Grasslands (RPG) cover $>7.5 \times$ $10^{5} \mathrm{~km}^{2}$ in the large plains of central-east Argentina, southern Brazil, and Uruguay (Soriano 1991, Paruelo et al. 2007; Fig. 1). The mean annual temperature varies from $20^{\circ} \mathrm{C}$ in the north to $13^{\circ} \mathrm{C}$ in the south, and the annual precipitation varies from $1800 \mathrm{~mm}$ in the northeast to $400 \mathrm{~mm}$ in the southwest (Food and Agriculture Organization 1985). Mollisols are the dominant soils, with Alfisols, Lithosols, Ultisols, Vertisols, Entisols, and Oxisols occupying smaller areas (Ministério da Agricultura-Brasil 1973, Instituto Nacional de Tecnología Agropecuaria-Secretaría de Agricultura, Ganadería y Pesca 1990, Instituto Brasileiro de Geografia e Estatística/Empresa Brasileira de Pesquisa Agropecuária 1991). Prairie and steppe codominated by $\mathrm{C}_{3}$ species and $\mathrm{C}_{4}$ Poaceae species are the main vegetation types (Soriano 1991, Burkart et al. 1998). The main annual crops are soybean, maize, sunflower, wheat, rice, and oat (Dirección de Estadísticas Agropecuarias-Ministerio de Ganadería, Agricultura, y Pesca 2003a, Instituto Brasileiro de Geografia e Estatística 2002, Secretaría de Agricultura, Ganadería, Pesca, y Alimentos 2004). Eucalyptus and pine plantations are important land cover in the wettest portion of the region (Sarli 2004, Jobbágy et al. 2006).

Several natural subunits can be distinguished according to geomorphology, soils, drainage, and physiographic and vegetation characteristics: the Rolling, Southern, Flooding, Flat Inland, West Inland, and Mesopotamic Pampas, and the Southern and Northern Campos (León 1991). We focused on eight pilot areas (Landsat scenes) distributed across the main environmental (mainly climatic and edaphic) and land-use history gradients. These areas included samples from all subunits of the RPG (Fig. $1)$. 
Fig. 1. (A) Location of the Río de la Plata Grasslands (RPG) ecosystem (in orange). (B) Subunits and pilot areas within the RPG; numbers within boxes correspond to the path/row of the Landsat scene. Internal political subdivisions are shown only within Argentina and Brazil (gray lines).
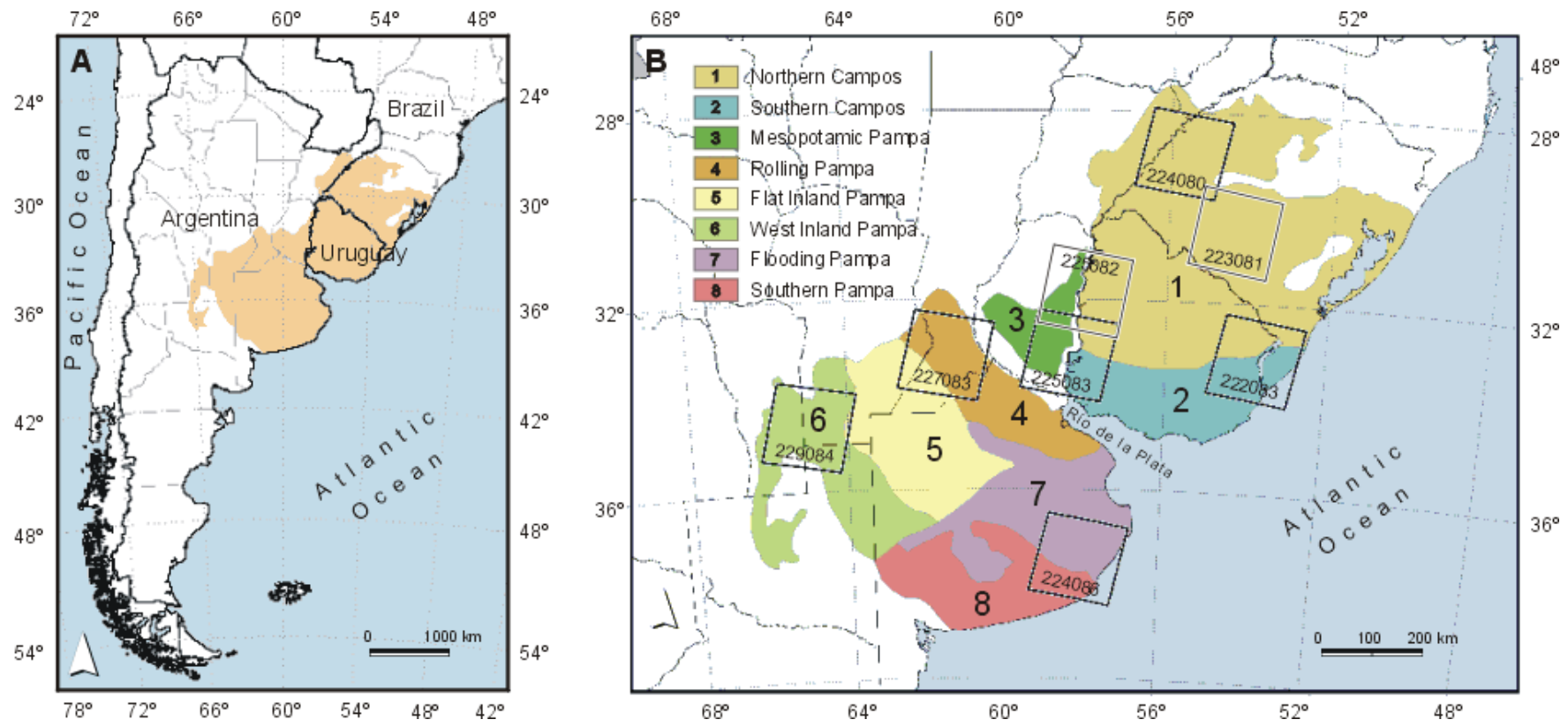

\section{Land cover and land-use characterization}

We analyzed Landsat Thematic Mapper (TM) and Enhanced Thematic Mapper Plus remotely sensed information with a spatial resolution of $30 \mathrm{~m}$ to characterize the land use and land cover (LULC) for two periods: 1985-1989 and 2002-2004. The list of satellite images used in the classification of the pilot areas (Landsat scenes) and details of the geometric, radiometric, and atmospheric corrections are provided in Appendix 1.

Because ground-truth information was not available for every scene and time period, we performed unsupervised classifications using the ISODATA algorithm following two approaches. We used the first approach for cases for which we had more than two images. We calculated the normalized difference vegetation index (NDVI) to create a temporal series that captured the phenological changes in vegetation (Lloyd 1990, Guerschman et al. 2003):

\section{$N D V I=(N I R-R) /(N I R+R)$}

where NIR is surface reflectance in the near infrared region (band 4 of Landsat TM) and $R$ is surface reflectance in the red region (band 3 of Landsat TM). There is a strong relationship between the NDVI and functional characteristics of vegetation, particularly between the fraction of absorbed radiation and net primary production (Tucker et al. 1985, Sellers et al. 1992, Paruelo et al. 2000). We used the second approach for all classification processes for the first period and for the 222/083 scene of the second period, for which only one or two images were available (Appendix 1). As Guerschman et al. (2003) demonstrated for NDVIbased classification, when the number of images considered decreases by one, the overall accuracy of the classification decreases considerably from 7 to $20 \%$. Thus, we performed the classification using all of the spectral information provided by the images, with the exception of the thermic channel 6 . We generated 50 spectral classes for the classifications of both approaches and for each scene and period. The resulting 800 spectral 
classes ( 50 classes $\times 2$ periods $\times 8$ scenes) were then labeled through visual comparison with a spectral library of the land cover types of the region based on ground-control points and polygons generated for the current and previous descriptions (Guerschman et al. 2003, Laboratorio de Análisis Regional y Teledetección 2004, Baldi et al. 2006; Appendix 1). Finally, the classifications for the second period were overlaid with the Moderate Resolution Imaging Spectroradiometer (MODIS) 13Q1 NDVI product of the same growing season, and we analyzed the phenological signature of the spectral classes in areas > 25 ha (four MODIS pixels). This in turn helped us to infer with more confidence the land cover types to which each spectral class belonged.

We identified five LULC types: (1) annual crops, i. e., summer crops, winter crops, and areas where winter and summer crops are sown in the same growing period; (2) forest and afforestation; (3) grassland, i.e., prairie and grass steppe; (4) water bodies; and (5) miscellaneous, e.g., dunes, salt marshes, and urban areas. We followed two different formal procedures to evaluate the classifications: When ground-truth information was available, we used pixel-based contingency matrixes (Congalton 1991); when no ground-truth information was available, we compared the results with statistical information provided by government offices at a county-based level using the Theils's partial inequality coefficients test when more than five counties were available (Smith and Rose 1995). For cases to which we could apply neither procedure, we performed qualitative informal evaluations using local expert advice. A detailed description of the evaluation procedures and precision of the LULC classification is provided in Appendix 2.

\section{Landscape structure and dynamics}

We quantified the landscape structure, i.e., composition and configuration, for the two study periods using several indices because no single metric can capture the complexity of the spatial arrangement of patches (Riitters et al. 1995; Table 1). To analyze the composition and configuration characteristics in both periods, we first slightly modified the LULC maps with a moving window median filter (three by three) to eliminate the saltand-pepper pattern. We then vectorized these maps, and polygons $<3600 \mathrm{~m}^{2}$ were eliminated, resulting in a minimum mapping unit (i.e., the smallest area entity to be mapped as a discrete area) of four Landsat pixels (Saura 2002). These maps were intersected with a 3383 square-cell grid of $8 \times 8 \mathrm{~km}$, and the percentage of the surface of each LULC type in each cell was calculated. We chose this cell size because it would incorporate several patches of different classes and their arrangement in space (i. e., landscape units) and would allow future comparisons with National Oceanic and Atmospheric Administration Airborne Very High Resolution Radiometer NDVI data. We then discarded annual crops, forest and afforestation, water bodies, and miscellaneous polygons and calculated three more metrics to characterize only the configuration of grasslands: effective mesh size, number of patches, and mean patch size. The effective mesh size (Jaeger 2000) is an index that simultaneously considers the patch size and the level of dissection and is not sensitive to the omission or inclusion of small patches. It reflects structural changes and has a monotonic response through different fragmentation stages such that the greater the effective mesh size, the lower the fragmentation level. We used this metric as a synthetic approach to analyze landscape fragmentation. The other two metrics were used as complementary measures to describe more specific features of the landscape configuration. The number of patches is a measure of the degree of subdivision of a cover type; careful interpretation must be made because it has a unimodal relationship with the amount of transformation. The mean patch size is a commonly used metric in spatial pattern analysis and is very sensitive to changes in the minimum mapping unit. All of the information was discriminated by pilot area, subunit, and country.

\section{Transition probabilities}

We described the transition probabilities $p_{\mathrm{i}} \rightarrow \mathrm{j}$ between LULC types between the study periods, allowing us to estimate the annual rates of change and at which land cover types' expense the changes occurred. The first step to compute $p_{\mathrm{i}} \rightarrow \mathrm{j}$ was the superposition of the two period's LULC maps. As a result, we obtained maps with 25 transition classes. We then intersected these maps with the $8 \times 8 \mathrm{~km}$ grid to calculate the transition probabilities as 
Table 1. The four landscape metrics considered.

\begin{tabular}{|c|c|c|c|}
\hline Metric & Formula $†$ & Units & Abbreviation \\
\hline Percentage of landscape & PLAND $=100 \cdot \frac{\sum_{\mathrm{i}=1}^{\mathrm{n}} A_{\mathrm{i}}}{A_{\mathrm{t}}}$ & percent & PLAND \\
\hline Number of patches & $\mathrm{NUMP}=n$ & patches & NUMP \\
\hline Mean patch size & $\mathrm{MEPS}=\frac{\sum_{\mathrm{i}=1}^{\mathrm{n}} A_{\mathrm{i}}}{n}$ & hectares & MEPS \\
\hline Effective mesh size & $\mathrm{EFMS}=\frac{\sum_{\mathrm{i}=1}^{\mathrm{n}}\left(A_{\mathrm{i}}\right)^{2}}{A_{\mathrm{t}}}$ & hectares & EFMS \\
\hline
\end{tabular}

$\dagger A_{\mathrm{i}}=$ patch area, $A_{\mathrm{t}}=$ total area of the grid unit, $n=$ number of patches.

$$
p_{\mathrm{i} \rightarrow \mathrm{j}, \mathrm{k}}=\frac{A_{\mathrm{i} \rightarrow \mathrm{j}, \mathrm{k}}}{A_{\mathrm{i}, \mathrm{t}=0, \mathrm{k}}} \cdot \frac{1}{\Delta t}
$$

where $A_{\mathrm{i}}$ is the area occupied by LULC class $i, A_{\mathrm{i}} \rightarrow \mathrm{j}$ is the area of transition class $i \rightarrow j, t=0$ is the first study period, $\Delta t$ is the number of years between the first and second study periods, and $k$ is a grid cell. Because of their ecological and socioeconomic relevance, we only analyzed the following transitions: grassland to cropland, cropland to cropland, cropland to grassland, and grassland to forest-afforestation. The information was discriminated by pilot area, subunit, and country.

\section{RESULTS}

\section{Land cover and land-use characterization}

For the approximately $2.65 \times 10^{5} \mathrm{~km}^{2}$ of area classified in the 1985-1989 and 2002-2004 periods, grassland cover decreased from 67.4 to $61.4 \%$ (from $151,320 \mathrm{~km}^{2}$ to $137,817 \mathrm{~km}^{2}$; a relative change of $-8.9 \%$ ) and the area under agriculture increased from 22.0 to $25.9 \%$ (from $49,348 \mathrm{~km}^{2}$ to $58,057 \mathrm{~km}^{2}$; a relative change of $+17.6 \%$; Table 2, Figs. 2 and A3.1). The contingency evaluations showed a high degree of total accuracy $\left(225 / 083_{\text {total accuracy }}=83.0 \%\right.$, $227 / 083_{\text {total accuracy }}=93.8 \%$ ). Theils's partial inequality coefficient tests indicated high concordance between the independent statistical information and our classifications (Tables A2.1A2.3). 


\section{Landscape structure and dynamics}

\section{Landscape composition}

The landscape composition showed marked differences between countries, subunits, and pilot areas between the study periods (Fig. 3A, B, Table A3.1). In 2002-2004, the Northern and Southern Campos and the Mesopotamic, Flooding, and Western Inland Pampas were still dominated by grassland. In contrast, the landscape of the Southern, Rolling, and Flat Inland Pampas was dominated by cropland. The Flooding Pampa had the highest proportion of grassland, at $85.1 \%$, whereas the Flat Inland Pampa had the lowest, at 20.2\%. The West Inland Pampa had the largest change in grassland cover between the periods (relative change in the percentage of landscape $\left[\Delta \mathrm{PLAND}_{\text {relative }}\right]=$ $-36.8 \%)$. Other subunits showed very small changes in grassland cover. These small changes could be a result of two mechanisms: grassland was not replaced by alternative land cover (e.g., Flooding Pampa, $\triangle \mathrm{PLAND}_{\text {relative }}=1.6 \%$ ), or the transformation occurred prior to 1985 (e.g., Southern Pampa, $\triangle$ PLAND relative $=2.8 \%$ ). The cells of the 227/083 scene, which was shared by Flat Inland and Rolling Pampas, had the highest cropland cover, at $\sim 75.0 \%$, whereas the Argentinean and Uruguayan Northern Campos had the lowest, at $<8.2 \%$, except for the $225 / 083$ Uruguayan scene. The highest increase in cropland area between the periods occurred in the Northern Campos of the 223/081 scene $(\Delta \mathrm{PLAND}=95.7 \%)$.

Only $8.6 \%$ of the region was covered by complex forest-afforestation (Table A3.1). However, in some portions of the Río de la Plata Grasslands (RPG), which include natural xerophytic forest and open woodland (e.g., West Inland Pampa), the cover of forest-afforestation accounted for $30.9 \%$ of the area. The northern subunits (Mesopotamic Pampa and Northern and Southern Campos) also had savanna and riparian forest, which explained the high values of forest-afforestation $\left(\right.$ PLAND $_{\text {average }}=$ $6.3 \%)$. The change in the cover of this class was relatively small $(\triangle \mathrm{PLAND}$ northern subunits $=5.6 \%)$; however, it resulted from two simultaneous processes that may cancel each other: the reduction of riparian forest and the transformation of grassland to exotic species afforestation. In the maps generated for the second period, large patches of afforested areas were evident on both margins of the Uruguay River, particularly in Argentina and Uruguay. The afforested area in the rest of the RPG was insignificant (PLAND $\approx 1 \%$ ), corresponding to urban or peri-urban tree formations (i.e., windbreak hedges, parks).

The Argentine and Brazilian Northern Campos of the 224/080 scene and the Brazilian and Uruguayan Campos of the 225/082-083 scenes allowed the analysis of the effect of policies and land-use history on landscape structure and dynamics (Table A3.1). In the former scene, the differences were very important because the countries had completely different initial patterns and trends. In Argentina, the dominant initial grassland cover (86.7\%) decreased in association with an increase in cropland and afforestation, whereas in Brazil, the important initial cropped area decreased by $17.9 \%$ (from 23.9 to $19.6 \%$ ). In the latter scenes, even though the initial situations were different, with the Brazilian side much more transformed than the Uruguayan side, the trends of change were similar, with a marked increase in agricultural activity in the Uruguayan Southern Campos $\left(\triangle \mathrm{PLAND}_{\text {average }}=\right.$ $74.8 \%$ ). A more flexible comparison between countries was performed by comparing the Campos and the Mesopotamic Pampa at the ArgentinaUruguay border. On average, the relative change in grassland was much higher in the grid cells in Argentina than in Uruguay $(-15.2$ vs. $-3.9 \%$, respectively) and was mainly associated with an expansion of cropland.

\section{Landscape configuration}

The Flat Inland and Rolling Pampas subunits displayed the highest grassland fragmentation, measured by the effective mesh size (EFMS $=150$ ha and 334 ha, respectively; Fig. 4, Table A3.2). Scattered grassland patches of small size (number of patches [NUMP] > 63 patches, mean patch size [MNPS] < 30 ha; Table A3.2) occurred within the agricultural matrix. The West Inland Pampa showed a pattern that was similar (EFMS = 996 ha), but highly spatially variable. Agricultural areas in this subunit are more important in the east $(\sim 18 \%$ of cells with $>50 \%$ of agricultural cover), and natural and seminatural grassland areas are important in the west $(22 \%$ cells with $>50 \%$ of grassland cover; Fig. A3.1). The Flooding Pampa was the least fragmented subunit $($ EFMS $=5048 \mathrm{ha})$, as fewer and larger seminatural or natural grassland patches constituted the landscape matrix (MNPS $=2523$ ha, NUMP $=8.8$ patches). Both Northern and Southern Campos had low to intermediate levels of fragmentation, in some cases, as low as that of 
Table 2. Area of each of five land-use and land cover types for the entire study region in two periods and the relative change in area between the two periods.

\begin{tabular}{lcccccc}
\hline \hline Period & $\begin{array}{c}\text { Unit of } \\
\text { measure }\end{array}$ & Cropland & Grassland & $\begin{array}{c}\text { Forest and } \\
\text { afforestation }\end{array}$ & Water bodies & Miscellaneous \\
\hline $1985-1989$ & $\mathrm{~km}^{2}$ & 49348.6 & 151320.3 & 15033.9 & 7384.6 & 1294.6 \\
& $\%$ & 22.0 & 67.4 & 6.7 & 3.3 & 0.6 \\
$2002-2004$ & $\mathrm{~km}^{2}$ & 58057.6 & 137817.9 & 19402.5 & 8675.5 & 415.7 \\
& $\%$ & 25.9 & 61.4 & 8.6 & 3.9 & 0.2 \\
Relative change & $\%$ & 17.6 & -8.9 & 29.1 & 17.5 & -67.9 \\
\hline
\end{tabular}

Note: The relative change was calculated as $\Delta_{\text {relative }}=100 \times\left(Y_{\text {final }}-Y_{\text {initial }}\right) / Y_{\text {initial }}$, where $Y$ is the area of the land-use and land cover type.

Flooding Pampa. However, these subunits had several large cropland foci within the grassland matrix; e.g., in the Northern Campos, $\sim 17 \%$ of the cells had $>30 \%$ of their surface in agriculture (Fig. A3.1). The Southern and Mesopotamic Pampas had intermediate fragmentation levels $($ EFMS $=1382$ ha and average of the two pilot areas in the subunit $=2978$ ha, respectively), with patches of low to intermediate size (EFMS $=104$ ha and average $=$ 692 ha).

The Flat and West Inland Pampas had the largest change in grassland fragmentation $\left(\Delta \mathrm{EFMS}_{\text {relative }}>\right.$ $40.5 \%$; Fig. 4). However, the ecological consequences of this change were quite different between the subunits. The Flat Pampa was already dominated by agricultural activities in the first study period, whereas the West Inland Pampa was initially dominated by grassland.

\section{Transition probabilities}

Grassland showed the highest annual probability of changing to cropland in the Flat Inland and Rolling Pampas $\left(p_{\mathrm{G}} \rightarrow \mathrm{C}=3.7 \times 10^{-2}\right.$ and $p_{\mathrm{G}} \rightarrow \mathrm{C}=3.6 \times$ $10^{-2}$, respectively; Fig. 5). In these two subunits, a given land parcel had the highest probability of remaining under cultivation $\left(p_{\mathrm{C} \rightarrow \mathrm{C}}=5.2 \times 10^{-2}\right.$ and $p_{\mathrm{C} \rightarrow \mathrm{C}}=5.2 \times 10^{-2}$, respectively), and the lowest probability of being abandoned once it became cultivated $\left(p_{\mathrm{C} \rightarrow \mathrm{G}}=9.2 \times 10^{-3}\right.$ and $p_{\mathrm{C} \rightarrow \mathrm{G}}$ $=9.5 \times 10^{-3}$, respectively). These results indicate the expansion of agriculture over the few remnant grasslands (Fig. A3.1). The Flooding Pampa, the Northern Campos scenes (except 224/080), and the Uruguayan scene $222 / 083$ had low values for grassland-to-cropland transition $\left(p_{\mathrm{G}} \rightarrow \mathrm{C}<8.9 \times\right.$ $\left.10^{-3}\right)$ and for the persistence of cropland $\left(p_{\mathrm{C} \rightarrow \mathrm{C}}<\right.$ $1.4 \times 10^{-2}$ ), and high values for cropland-tograssland transition $\left(p_{\mathrm{C} \rightarrow \mathrm{G}}>4.3 \times 10^{-2}\right.$, except for the Brazilian scenes $222 / 083$ and 223/081). The West Inland and Mesopotamic Pampas exhibited intermediate grassland-to-cropland transition probabilities because grassland persisted as the landscape matrix. An important advance of woody cover was detected in the West Inland Pampa; however, high values for the grassland-to-forest-afforestation transition do not imply changes in the afforested area, which is negligible in this subunit, but rather an increase in the native woody species distribution. In contrast, the grassland-to-forest-afforestation transition probabilities for the Mesopotamic Pampa (average $\left.p_{\mathrm{G} \rightarrow \mathrm{FA}}=2.8 \times 10^{-3}\right)$ and Northern and Southern Campos (average $p_{\mathrm{G} \rightarrow \mathrm{FA}}=3.1 \times 10^{-3}$ ) reflect the expansion of afforested areas (Dirección de Estadísticas Agropecuarias-Ministerio de Ganadería, Agricultura, y Pesca 2003b, Sarli 2004). 
Fig. 2. Land-use and land cover maps for (A) 1985-1989 and (B) 2002-2004. Light gray lines indicate subunit boundaries. The pie chart indicates the percentage of each land-use and land cover type for each period.
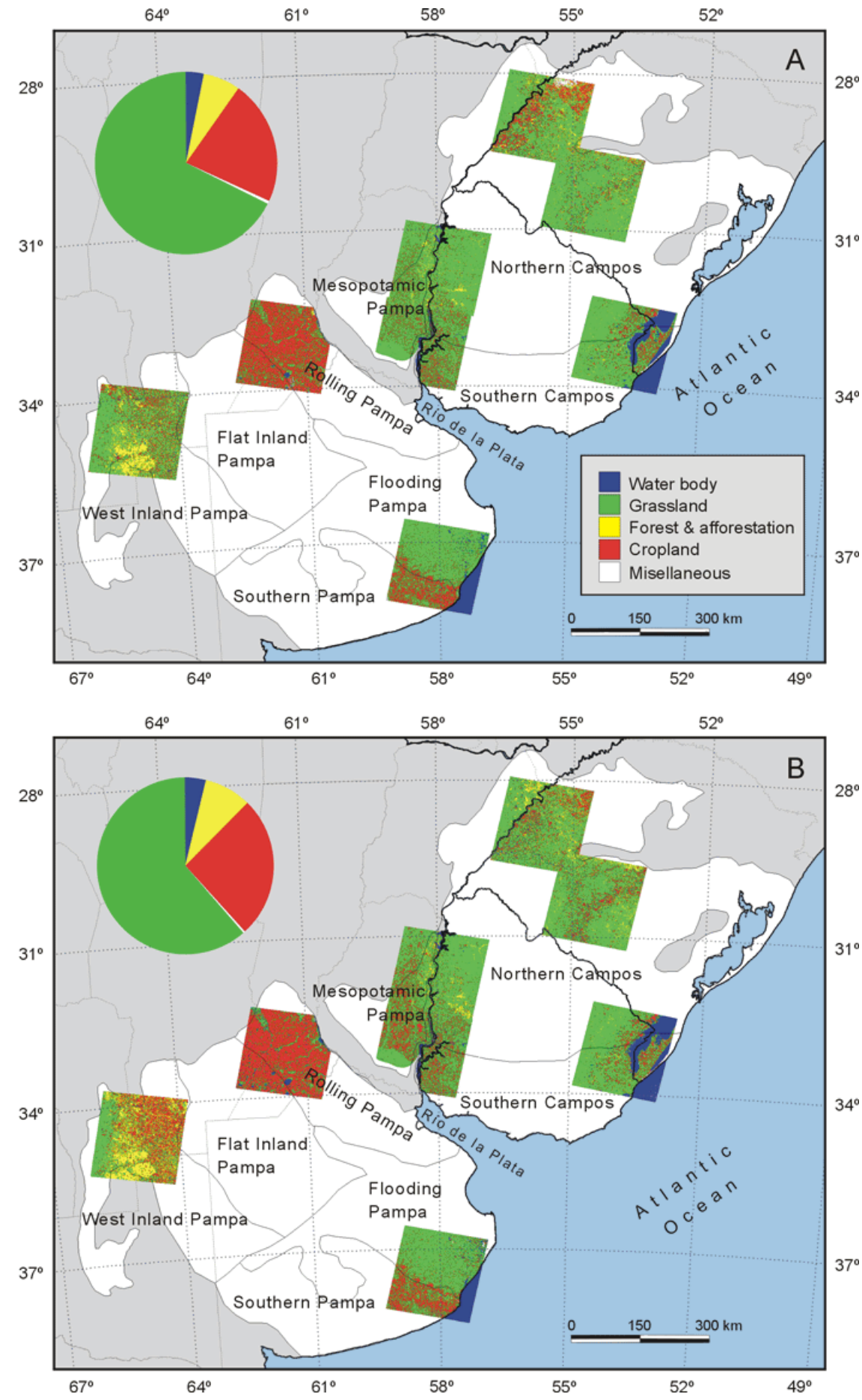
Fig. 3. Percentage of land cover (PLAND) for (A) grassland and (B) cropland for 1985-1989 and 20022004, discriminated by pilot area, subunit, and country. Dotted lines indicate the thresholds of relative change in grassland area, calculated as $\Delta_{\text {relative }}=100\left(Y_{\text {final }}-Y_{\text {initial }}\right) / Y_{\text {initial }}$, where $Y$ is the area of the landuse and land cover type. The abbreviations indicate the subunit (letters) and pilot area (Landsat scene; numerals): $\mathrm{NOC}=$ Northern Campos, $\mathrm{SOC}=$ Southern Campos, $\mathrm{SOP}=$ Southern Pampa, FLP $=$ Flooding Pampa, WIP = West Inland Pampa, FIP = Flat Inland Pampa, MEP = Mesopotamic Pampa, $\mathrm{ROP}=$ Rolling Pampa, $1=222 / 083,2=223 / 081,3=224 / 080,4=224 / 086,5=225 / 082,6=225 / 083$, $7=227 / 083$, and $8=229 / 084$. The number of grid cells included in each combination is given in Table A3.1.

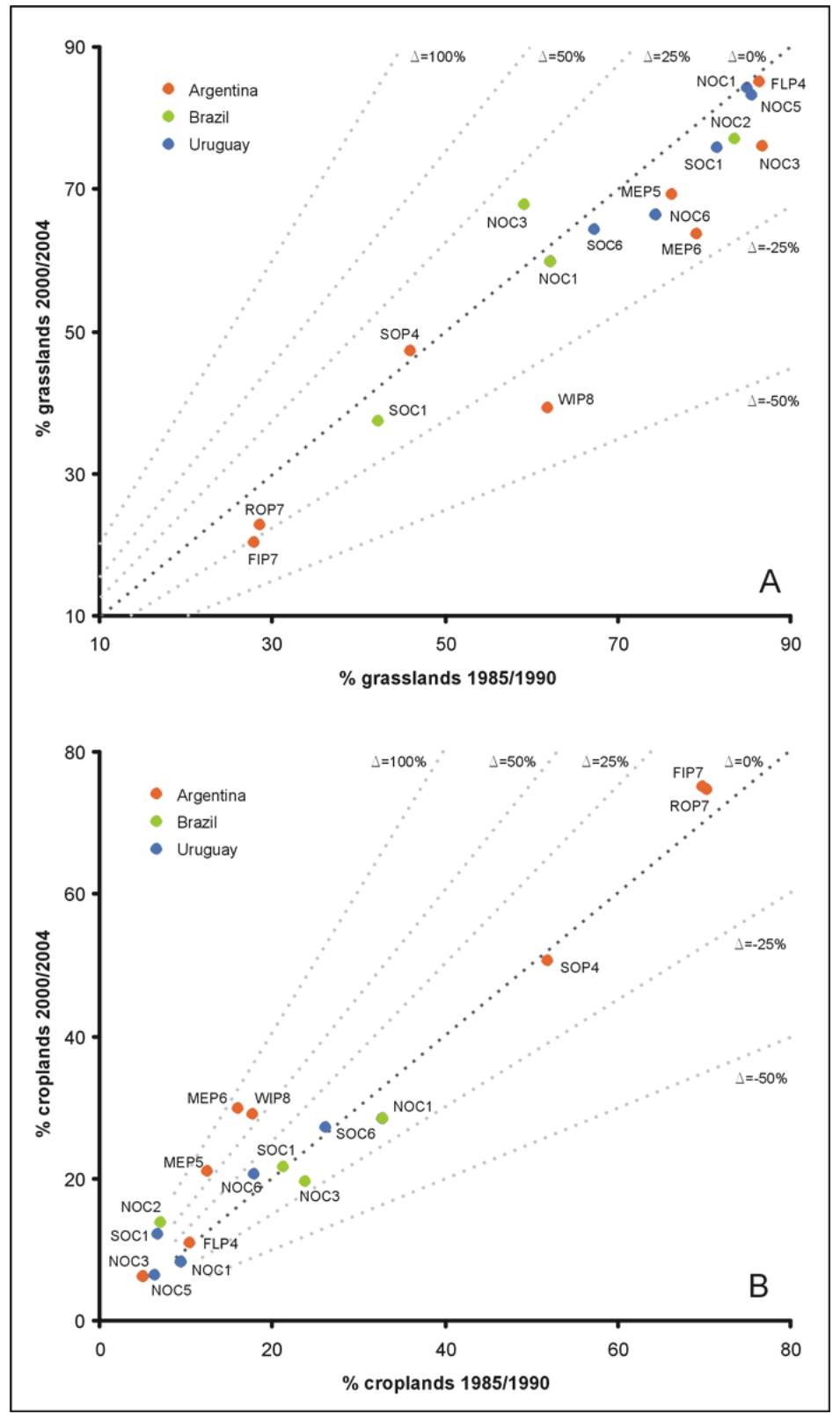


Fig. 4. Effective mesh size (EFMS) for 1985-1989 and 2002-2004 for grassland discriminated by pilot area, subunit, and country. Dotted lines indicate the thresholds of relative change in EFMS, calculated as $\Delta_{\text {relative }}=100\left(Y_{\text {final }}-Y_{\text {initial }}\right) / Y_{\text {initial }}$, where $Y$ is the EFMS. The abbreviations indicate the subunit (letters) and pilot area (Landsat scene; numerals): $\mathrm{NOC}=$ Northern Campos, $\mathrm{SOC}=$ Southern Campos, $\mathrm{SOP}=$ Southern Pampa, FLP = Flooding Pampa, WIP = West Inland Pampa, FIP = Flat Inland Pampa, MEP = Mesopotamic Pampa, ROP = Rolling Pampa, $1=222 / 083,2=223 / 081,3=224 / 080,4=224 / 086,5=$ $225 / 082,6=225 / 083,7=227 / 083$, and $8=229 / 084$. The number of grid cells included in each combination is given in Table A3.1.

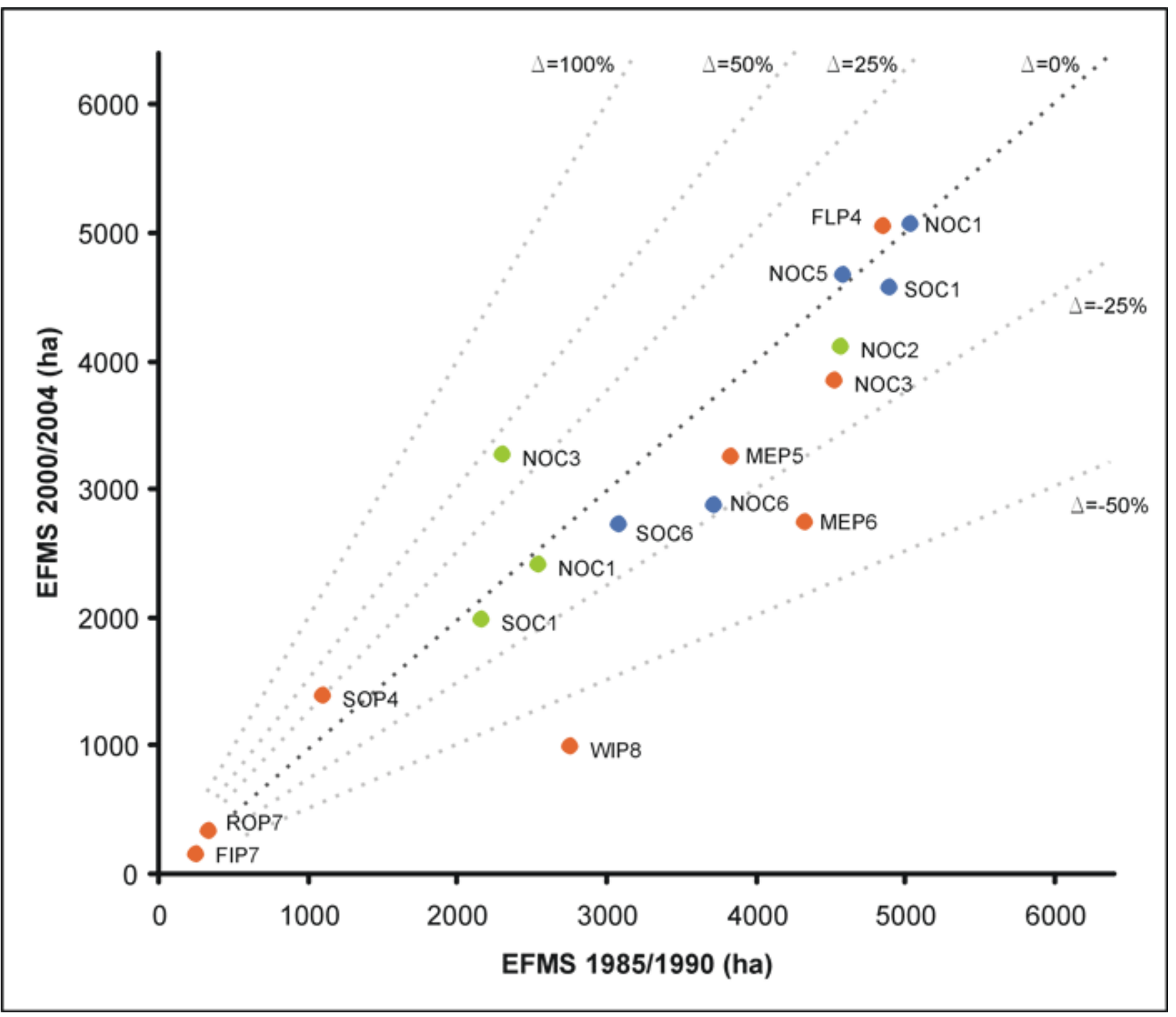


Again, the strict comparison between shared scenes showed that the country limits determine the landuse dynamics. For example, on the Argentinean side of scene 224/080, the grassland-to-forestafforestation transition was high, whereas it was negligible on the Brazilian side. In the scenes shared by Brazil and Uruguay (Northern and Southern Campos), the main difference was that the croplandto-grassland transition was much higher in Uruguay than in Brazil (average $p_{\mathrm{C} \rightarrow \mathrm{G}}$ of $4.4 \times 10^{-2}$ vs. $3.4 \times 10^{-2}$, respectively), indicating a high rate of rotation in land use because the grassland cover did not change substantially in the involved scenes and subunits.

Finally, for landscapes that had a similar composition in both time periods, annual transition probabilities allowed us to discriminate between those that were static (i.e., individual patches in which the same cover was maintained over time) and those that were dynamic (i.e., patches in which land cover changed over time). As an example, $7 \%$ of cells for Rolling Pampa had grassland-tocropland transition probabilities $>3.1 \times 10^{-2}$, with a relative change in grassland cover of $<15 \%$.

\section{DISCUSSION}

\section{Landscape composition and dynamics}

Our analysis provided a detailed description of the dynamics of land-use and land cover patterns over a large fraction of the Río de la Plata Grasslands (RPG): $\sim 35 \%$ of the biogeographic region. A high proportion of the analyzed area is still covered by natural and seminatural grassland (61.4\%). However, the relative abundance of the land-use and land cover types differed among pilot areas (scenes) and subunits, as well as between countries within pilot areas or subunits.

Cropland predominated in the Southern, Rolling, and Inland Flat Pampas. In the first two subunits, the high cover in both periods is a result of the relatively long agricultural history combined with natural advantages for agricultural activities. At the end of the 19th century, a major modification began in these subunits with the arrival of European migrants escaping from starvation, poverty, and wars; the expansion of transportation ways; and government and private colonization plans (Gaignard 1989, Hall et al. 1992, Viglizzo et al. 2001). This colonization trend was not exclusive to
Argentina; the Campos of Brazil and Uruguay were the scenes of arrival for thousands of Italian, Spanish, German, and Russian migrants, among others. Most of the agriculture-dominated areas in the Campos originated during this period.

We identified new areas of agricultural expansion in the Mesopotamic and Inland Pampas, the Uruguayan Southern Campos (scene 222/083), and the Brazilian Northern Campos (scene 223/081) that were associated with technological factors and market conditions. Remarkably, we also found a pattern of land abandonment for the Brazilian agricultural foci of scenes 222/083 and 224/080, which contrasts not only with what occurred in the other subunits and countries, but also with the general trend in Brazil, where, for soybean croplands alone, an increase of $3.6 \%$ was registered during 1990-2001 (Pessoa Brandão et al. 2006, Overbeck et al. 2007).

In a markedly different situation, the Flooding Pampa did not change much during the 1985-2005 period. This subunit and the predominant grasslanddominated areas of the Northern and Southern Campos were devoted to extensive grazing activities from the beginning of colonization by Europeans (Hall et al. 1992, Viglizzo et al. 2001, Overbeck et al. 2007). In the Flooding Pampa, the high levels of alkalinity and sodicity in soils and the frequent floods impose serious constrains to agricultural development (Instituto Nacional de Tecnología Agropecuaria-Secretaría de Agricultura, Ganadería y Pesca 1990).

Averaging subunits and pilot areas, the most important landscape transformations occurred in Argentina, where grassland cover suffered a $16.3 \%$ reduction between the study periods. We also identified an important increase in cropland area in Uruguay between the study periods. Such expansion followed a several decades long phase of cropland retraction (Dirección de Estadísticas AgropecuariasMinisterio de Ganadería, Agricultura, y Pesca $2003 c$ ). On both margins of the Uruguay River in Argentina and Uruguay, a new land-use type, i.e., pine and eucalyptus afforestation, showed an important increase as a result of economic and political incentives (Sarli 2004, Jobbágy et al. 2006). In both countries, planted forest replaced rangeland because the grassland-to-forest-afforestation transition probabilities were higher than those for cropland to forest-afforestation. In Brazil, the discovered heterogeneous pattern of increases and 
Fig. 5. Transition probabilities for grassland to cropland $(\mathrm{G} \rightarrow \mathrm{C})$, cropland to cropland $(\mathrm{C} \rightarrow \mathrm{C})$, cropland to grassland $(\mathrm{C} \rightarrow \mathrm{G})$, and grassland to forest-afforestation $(\mathrm{G} \rightarrow \mathrm{FA})$ discriminated by pilot area (Landsat scene), subunit, and country. The abbreviations indicate the subunit (letters) and pilot area (Landsat scene; numerals): NOC = Northern Campos, $\mathrm{SOC}=$ Southern Campos, $\mathrm{SOP}=$ Southern Pampa, FLP = Flooding Pampa, WIP = West Inland Pampa, FIP = Flat Inland Pampa, MEP = Mesopotamic Pampa, $\mathrm{ROP}=$ Rolling Pampa, $1=222 / 083,2=223 / 081,3=224 / 080,4=224 / 086,5=225 / 082,6=225 / 083$, $7=227 / 083$, and $8=229 / 084$. The number of grid cells included in each combination is given in Table A3.1.

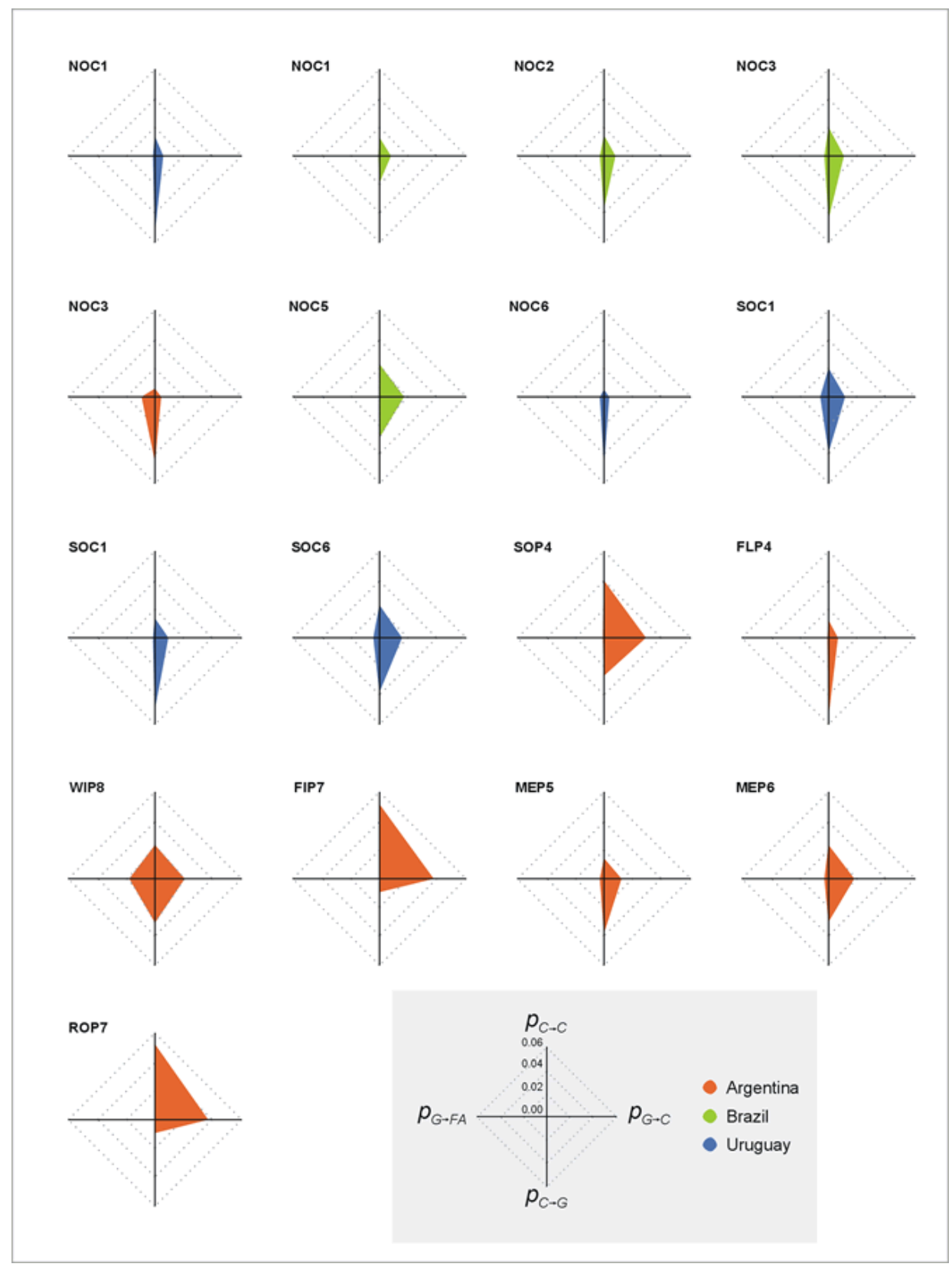


decreases in agricultural area offers new avenues of study because the underlying causes and consequences of land abandonment are not clear based on the available data and local expert opinion.

Preliminary results indicate that almost half of the spatial variability in changes between the study periods may be associated with environmental factors, mainly edaphic (Baldi 2007). The differences in relative changes in area and transition probabilities across political boundaries indicate that aside from environmental controls, the land cover distribution is strongly influenced by social, economic, and technological factors, which in turn are influenced by national policies. However, there is no clear understanding of the reasons behind the spatial heterogeneity of the changes, and almost no quantitative information is available on these factors as drivers of land-use and land cover dynamics. We have provided basic input for such analyses. The lack of a quantitative, spatially explicit description of land cover changes is a major shortcoming in the development of hypotheses about the processes involved and the analysis of their consequences (Paruelo et al. 2004). Therefore, to understand the human controls underlying the changes remains a major challenge for both social and environmental scientists.

\section{Landscape configuration and dynamics in relation to the process of grassland fragmentation}

The impoverishment of the native biota in the RPG region is remarkable, and the main causes are the modification of ecosystem functional traits caused by biotic invasion, grazing activities, and other factors, and by the reduction and fragmentation of the grassland area (Bilenca and Miñarro 2004). The different situations of fragmentation in the region can be classified based on the analysis of different landscape metrics that capture fundamental components of spatial pattern (Riitters et al. 1995) and following the scheme of stages proposed by Forman (1995) and Jaeger (2000; see also Baldi et al. 2006; Fig. 6A). Thus, the Flooding Pampa is at an incision or perforation stage in which the grassland matrix is only interrupted by small agricultural plots, transportation lines, streams, channels, and ponds (Figs. 6B and A3.1). The Northern and Southern Campos grasslands are at a perforation or dissection stage in which grassland is the landscape matrix, but there are a large number of cropland and afforestation foci (Figs. 6C and A3.1). In the West Inland and Mesopotamic Pampas, an active fragmentation process is operating and the landscapes are at a stage of dissection or dissipation (Figs. 6D and A3.1). In these two subunits, the pattern of cropland parcels superimposed on the grassland matrix exhibits a codominance of grassland and cropland patches. In the Southern, Rolling, and Flat Inland Pampas, the grasslands are at a shrinkage or attrition stage characterized by small, isolated, simple-shaped grassland patches (Figs. 6E and A3.1). Nevertheless, because of the high cover of cropland in these subunits, considerable changes are not expected in the near future. Westward, in the Flat Inland Pampa, the patterns are slightly different: cropland is located in elevated areas and grassland is located in lowlands.

Finally, on average for the entire region, the change in the number of patches was 3.5 times greater and the mean patch size was 2.2 times greater than the change in the percentage of landscape occupied by grassland. Thus, the consequences of losing natural grassland go beyond the changes in the area and affect the continuity and biotic exchange among remnants patches and the viability of populations because of reductions in patch size.

Responses to this article can be read online at: http://www.ecologyandsociety.org/voll3/iss2/art6/responses/

\section{Acknowledgments:}

This work was funded by a grant from the InterAmerican Institute for Global Change Research (IAI, CRN II 2031), which is supported by the U.S. National Science Foundation (Grant GEO-0452325), by Sensor-TTC project grantno. 003874, CONICET grant PICT 06-12186, and UBACyT grants GO-71 and GO-78. The CONAE (Comision Nacional de Actividades Espaciales, Argentina) and the University of Maryland (USA) provided free Landsat information. We thank Roxana Aragón, Marcos Texeira, Margareth Simões, Marcos Pereira, Claudio Sáenz, Martín Oesterheld, Heitor Coutinho, Chilo Grau, Ana Cingolani, and three anonymous reviewers for their support and comments. 
Fig. 6. (A) Schematic representation of the fragmentation process at different stages, modified from Forman (1995) and Jaeger (2000). Gray represents the original land cover; white represents anthropogenic or new land cover. Landscape cover type in 2002-2004 in: (B) Flooding Pampa, (C) Northern Campos, (D) Mesopotamic Pampa, and (E) Rolling Pampa.

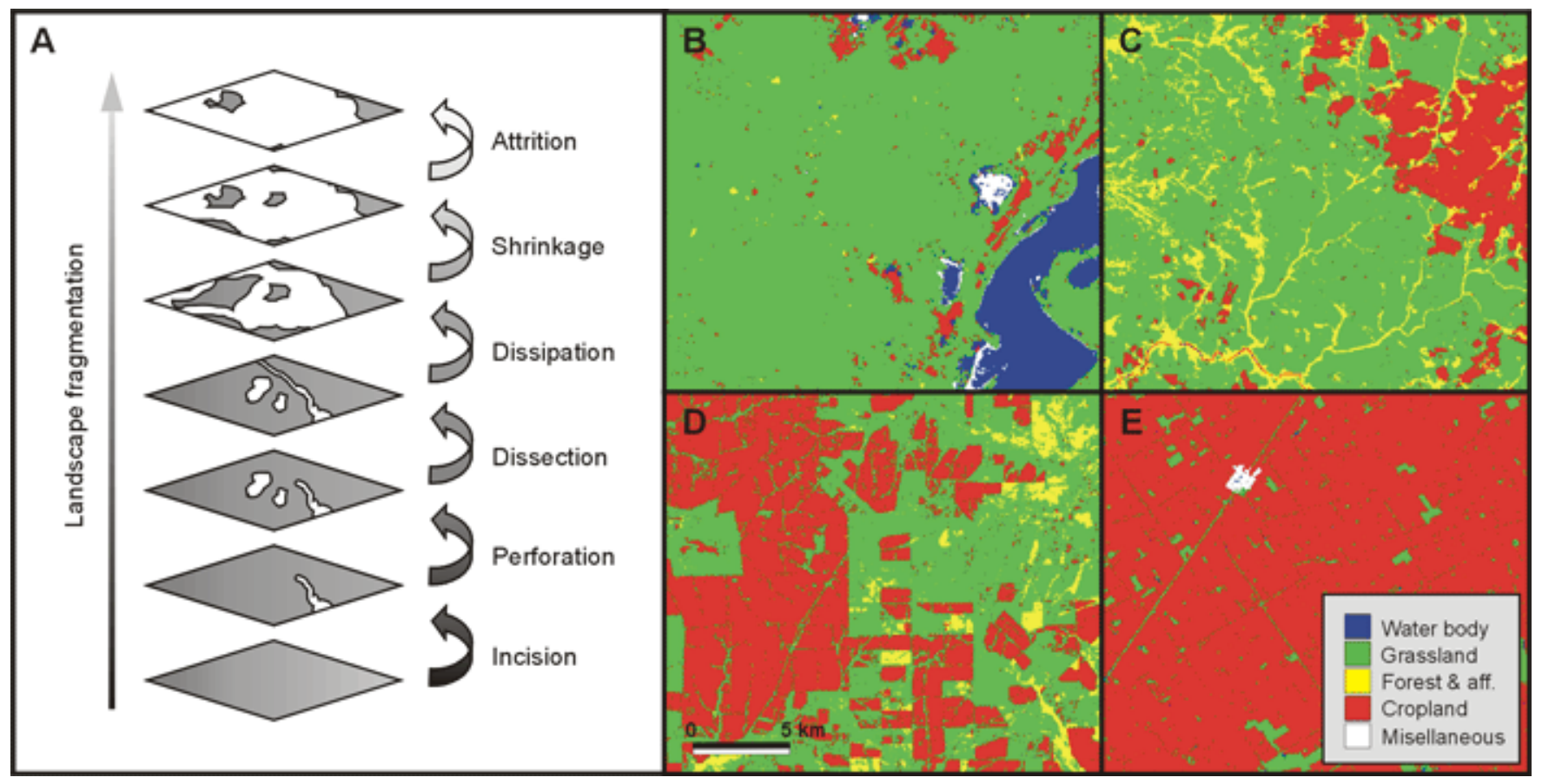

\section{LITERATURE CITED}

Alexandratos, N. 1999. World food and agriculture: outlook for the medium and longer term. Proceedings of the National Academy of Sciences 96(11):5908-5914.

Baldi, G. 2007. Cambios en la estructura del paisaje en la región de los Pastizales del Río de la Plata (período 1985-2005). Thesis. Universidad de Buenos Aires, Buenos Aires, Argentina.

Baldi, G., J. P. Guerschman, and J. M. Paruelo. 2006. Characterizing fragmentation in temperate South America grasslands. Agriculture, Ecosystems and Environment 116(3-4):197-208.

Bilenca, D. N., and F. O. Miñarro. 2004. Identificación de áreas valiosas de pastizal (IVPs) en las pampas y campos de Argentina, Uruguay y sur de Brasil. Fundación Vida Silvestre Argentina,
Buenos Aires, Argentina.

Burkart, S. E., R. J. C. León, S. B. Perelman, and M. Agnusdei. 1998. The grasslands of the flooding pampa (Argentina): floristic heterogeneity of natural communities of the southern Río Salado basin. Coenoses 13:17-27.

Congalton, R. G. 1991. A review of assessing the accuracy of classifications of remotely sensed data. Remote Sensing of Environment 37(1):35-46.

Dirección de Estadísticas AgropecuariasMinisterio de Ganadería, Agricultura, y Pesca. 2000. Censo general agropecuario. Dirección de Estadísticas Agropecuarias-Ministerio de Ganadería, Agricultura, y Pesca, Montevideo, Uruguay.

Dirección de Estadísticas AgropecuariasMinisterio de Ganadería, Agricultura, y Pesca. 2003a. El cultivo de arroz en Uruguay: contribución 
a su conocimiento. Dirección de Estadísticas Agropecuarias-Ministerio de Ganadería, Agricultura, y Pesca, Montevideo, Uruguay. Available online at: www.mgap.gub.uy/Diea/Rubros/Arroz/Arroz Junio2003. pdf.

Dirección de Estadísticas AgropecuariasMinisterio de Ganadería, Agricultura, y Pesca. 2003b. La actividad forestal a través del censo agropecuario. Dirección de Estadísticas AgropecuariasMinisterio de Ganadería, Agricultura, y Pesca, Montevideo, Uruguay. Available online at: www.m gap.gub.uy/diea/Rubros/Forestacion/Forestación ju nio2003.pdf.

Dirección de Estadísticas AgropecuariasMinisterio de Ganadería, Agricultura, y Pesca. 2003c. La agricultura de secano en Uruguay: contribución a su conocimiento. Dirección de Estadísticas Agropecuarias-Ministerio de Ganadería, Agricultura, y Pesca, Montevideo, Uruguay. Available online at: www.mgap.gub.uy/DIEA/Rubros/ AgriculturadeSecano/AgriculturadeSecano Junio2003. pdf.

Ehrlich, P. R., and A. H. Ehrlich. 1992. The value of biodiversity. Ambio 21:219-226.

Fahrig, L., and G. Merriam. 1994. Conservation of fragmented populations. Conservation Biology 8 (1):50-59.

Foley, J. A., R. DeFries, G. P. Asner, C. Barford, G. Bonan, S. R. Carpenter, F. S. Chapin, M. T. Coe, G. C. Daily, H. K. Gibbs, J. H. Helkowski, T. Holloway, E. A. Howard, C. J. Kucharik, C. Monfreda, J. A. Patz, I. C. Prentice, N. Ramankutty, and P. K. Snyder. 2005. Global consequences of land use. Science 309:570-574.

Food and Agriculture Organization. 1985. Agroclimatological data for Latin America and the Caribbean. Food and Agriculture Organization, Rome, Italy.

Forman, R. T. T. 1995. Land mosaics: the ecology of landscapes and regions. Cambridge University Press, Cambridge, UK.

Gaignard, R. 1989. La pampa Argentina. Ocupación, poblamiento, explotación. De la conquista a la crisis mundial (1550-1930). Ediciones Solar, Buenos Aires, Argentina.
Galetto, L., R. Aguilar, M. Musicante, J. Astegiano, A. Ferreras, M. Jausoro, C. Torres, L. Ashworth, and C. Eynard. 2007. Fragmentación de hábitat, riqueza de polinizadores, polinización y reproducción de plantas nativas en el Bosque Chaqueño de Córdoba, Argentina. Ecología Austral 17(1):67-80.

Grau, H. R., T. M. Aide, J. K. Zimmerman, J. R. Thomlinson, E. Helmer, and X. Zou. 2003. The ecological consequences of socioeconomic and land-use changes in postagriculture Puerto Rico. Bioscience 53(12):1159-1168.

Guerschman, J. P., J. M. Paruelo, C. Di Bella, M. C. Giallorenzi, and F. Pacín. 2003. Land cover classification in the Argentine pampas using multitemporal LANDSAT TM data. International Journal of Remote Sensing 24(17):3381-3402.

Hall, A. J., C. M. Rebella, C. M. Ghersa, and J. P. Culot. 1992. Field-crop systems of the pampas. Pages 413-450 in C. J. Pearson, editor. Field crop ecosystems. Elsevier, Amsterdam, The Netherlands.

Hannah, L., J. L. Carr, and A. Lankerani. 1995. Human disturbance and natural habitat: a biome level analysis of a global data set. Biodiversity and Conservation 4(2):128-155.

Instituto Brasileiro de Geografia e Estatística. 2002. Produção agrícola municipal: culturas temporárias e permanentes. Volume 29. Instituto Brasileiro de Geografia e Estatística, Rio de Janeiro, Brazil. Available online at: http://www.ibge.gov.br/ home/estatistica/economia/pam/2002/default.shtm

Instituto Brasileiro de Geografia e Estatística/ Empresa Brasileira de Pesquisa Agropecuária. 1991. Mapa exploratório dos solos do Estado do Rio Grande do Sul. Page 264 in XXIII Congresso Brasileiro de Ciência do Solo. Sociedade Brasileira de Ciência do Solo/Universidade Federal do Rio Grande do Sul, Porto Alegre, Brazil.

Instituto Nacional de Tecnología AgropecuariaSecretaría de Agricultura, Ganadería y Pesca. 1990. Atlas de suelos de la República Argentina. Instituto Nacional de Tecnología AgropecuariaSecretaría de Agricultura, Ganadería y Pesca, Buenos Aires, Argentina. 
Jaeger, J. A. G. 2000. Landscape division, splitting index, and effective mesh size: new measures of landscape fragmentation. Landscape Ecology 15 (2):115-130.

Jobbágy, E. G., M. Vasallo, K. A. Farley, G. Piñeiro, M. F. Garbulsky, M. D. Nosetto, R. B. Jackson, and J. M. Paruelo. 2006. Forestación en pastizales: hacia una visión integral de sus oportunidades y costos ecológicos. Agrociencia $\mathbf{1 0}$ (2):109-124. Available online at: http://www.fagro. edu.uy/agrociencia/VOL10/2/pp109-124.pdf.

Kauppi, P. E., J. H. Ausubel, J. Fang, A. S. Mather, R. A. Sedjo, and P. E. Waggoner. 2006. Returning forests analyzed with the forest identity. Proceedings of the National Academy of Sciences 103(46):17574-17579.

Laboratorio de Análisis Regional y Teledetección. 2004. Estimación de áreas y distribución de las diferentes clases de cobertura de suelo durante el período inverno-primaveral para la Provincia de Buenos Aires. Universidad de Buenos Aires, Buenos Aires, Argentina. Available online at: http://www.a gro.uba.ar/users/lart/estimacionesagricolas/.

León, R. J. C. 1991. Geographic limits of the region, geomorphology and geology, regional subdivisions, floristic aspects, description of the vegetation. Pages 369-387 in R. T. Coupland, editor. Natural grasslands: introduction and western hemisphere. Elsevier, Amsterdam, The Netherlands.

Lloyd, D. 1990. A phenological classification of terrestrial vegetation cover using shortwave vegetation index imagery. International Journal of Remote Sensing 11(12):2269-2279.

Millennium Ecosystem Assessment. 2005. Ecosystems and human well-being: biodiversity synthesis. World Resources Institute, Washington, D.C., USA. Available online at: http://www.millen niumassessment.org/en/synthesis.aspx.

Ministério da Agricultura-Brasil. 1973. Levantamento de reconhecimento dos solos do Estado do Rio Grande do Sul. Technical Bulletin 30, MA/DPP/ DPP-SA/DRNR, Recife, Brazil.

Naef, F., S. Scherrer, and M. Weiler. 2002. A process based assessment of the potential to reduce flood runoff by land use change. Journal of Hydrology 267(1-2):74-79.
Nosetto, M. D., E. G. Jobbágy, and J. M. Paruelo. 2005. Land-use change and water losses: the case of grassland afforestation across a soil textural gradient in central Argentina. Global Change Biology 11(7):1101-1117.

Overbeck, G. E., S. C. Müller, A. Fidelis, J. Pfadenhauer, V. D. Pillar, C. C. Blanco, I. I. Boldrini, R. Both, and E. D. Forneck. 2007. Brazil's neglected biome: the South Brazilian Campos. Perspectives in Plant Ecology, Evolution and Systematics 9(2):101-116.

Paruelo, J. M., J. P. Guerschman, G. Baldi, and C. M. Di Bella. 2004 La estimaciên de la superficie agrícola. Antecedentes y una propuesta metodológica. Interciencia 29(8):421-427.

Paruelo, J. M., J. P. Guerschman, and S. R. Verón. 2005. Expansión agrícola y cambios en el uso del suelo. Ciencia Hoy 15(87):14-23.

Paruelo, J. M., E. G. Jobbágy, M. Oesterheld, R. A. Golluscio, and M. R. Aguiar. 2007. Grasslands and steppes of Patagonia and the Río de la Plata plains. Pages 232-248 in T. T. Veblen, K. R. Young, and A. R. Orme, editors. The physical geography of South America. Oxford University Press, Oxford, UK.

Paruelo, J. M., E. G. Jobbágy, O. E. Sala, W. K. Lauenroth, and I. C. Burke. 1998. Functional and structural convergence of temperate grassland and shrubland ecosystems. Ecological Applications 8 (1):194-206.

Paruelo, J. M., M. Oesterheld, C. M. Di Bella, M. Arzadum, J. Lafontaine, M. Cahuepé, and C. M. Rebella. 2000. Estimation of primary production of subhumid rangelands from remote sensing data. Applied Vegetation Science 3:189-195.

Pessoa Brandão,A. S., G. Castro de Rezende, and R. Wanderley da Costa Marques. 2006. Crescimento agrícola no Brasil no período 1999/2004: explosão da soja e da pecuária bovina e seu impacto sobre o meio ambiente. Economia Aplicada 10(2):249-266. [online] URL: http:// www.scielo.br/scielo.php?script $=$ sci_arttext\&pid $=$ S1413-80502006000200006\&lng=en\&nrm=iso.

Pielke, R. A., and R. Avissar. 1990. Influence of landscape structure on local and regional climate. Landscape Ecology 4(2-3):133-155. 
Ramankutty, N., and J.A. Foley. 1999. Estimating historical changes in global land cover: croplands from 1700 to 1992. Global Biogeochemical Cycles 13(4):997-1027.

Ramankutty, N., J. A. Foley, J. Norman, and K. McSweeney. 2002. The global distribution of cultivable lands: current patterns and sensitivity to possible climate change. Global Ecology and Biogeography 11(5):377-392.

Riitters, K. H., R. V. O’Neill, C. T. Hunsaker, J. D. Wickham, D. H. Yankee, S. P. Timmins, K. B. Jones, and B. L. Jackson. 1995. A factor analysis of landscape pattern and structure metrics. Landscape Ecology 10(1):23-39.

Secretaría de Agricultura, Ganadería, Pesca, y Alimentos. 2002. El quinquenio de la soja transgénica. Secretaría de Agricultura, Ganadería, Pesca, y Alimentos, Buenos Aires, Argentina.

Secretaría de Agricultura, Ganadería, Pesca, y Alimentos. 2004. Estimaciones agrícolas mensuales. Secretaría de Agricultura, Ganadería, Pesca, y Alimentos, Buenos Aires, Argentina.

Sala, O. E., and J. M. Paruelo. 1997. Ecosystem services in grasslands. Pages 237-252 in G. C. Daily, editor. Nature's services: societal dependence on natural ecosystems. Island Press, Washington, D. C., USA.

Sarli Canedo, V. P. 2004. Impacto del cambio en el uso del suelo sobre el funcionamiento ecosistémico, Departamentos de Paysandú y Río Negro, Uruguay. Thesis. Universidad de la República, Montevideo, Uruguay.

Saunders, D. A., R. J. Hobbs, and C. R. Margules. 1991. Biological consequences of ecosystem fragmentation: a review. Conservation Biology 5 (1):18-32.

Saura, S. 2002. Effects of minimum mapping unit on land cover data spatial configuration and composition. International Journal of Remote Sensing 23(22):4853-4880.

Sellers, P. J., J. A. Berry, G. J. Collatz, C. B. Field, and F. G. Hall. 1992. Canopy reflectance, photosynthesis, and transpiration. III. A reanalysis using improved leaf models and a new canopy integration scheme. Remote Sensing of Environment 42(3):187-216.

Smith, E. P., and K. A. Rose. 1995. Model goodness-of-fit analysis using regression and related techniques. Ecological Modelling $\mathbf{7 7}$ (1):49-64.

Soriano, A. 1991. Río de la Plata Grasslands. Pages 367-407 in R. Coupland, editor. Natural grasslands: introduction and Western Hemisphere. Elsevier, Amsterdam, The Netherlands.

Stumpf, R. P. 1992. Remote sensing of water clarity and suspended sediments in coastal waters: needs and solutions for pollution monitoring, control, and abatement. Pages 293-305 in Proceedings First Thematic Conference on Remote Sensing for Marine and Coastal Environmets. Environmental Research Institute of Michigan, Ann Arbor, Michigan, USA.

Tilman, D., J. Fargione, B. Wolff, C. D'Antonio, A. Dobson, R. Howarth, D. Schindler, W. H. Schlesinger, D. Simberloff, and D. Swackhamer. 2001. Forecasting agriculturally driven global environmental change. Science 292:281-284.

Tucker, C. J., J. R. G. Townshend, and T. E. Goff. 1985. African land-cover classification using satellite data. Science 227:369-375.

Vervoorst, F. B. 1967. La vegetación de la República Argentina. VII. Las comunidades vegetales de la depresión del salado. Instituto Nacional de Tecnologia Agropecuaria, Buenos Aires, Argentina.

Viglizzo, E. F., F. Lértora, A. J. Pordomingo, J. N. Bernardos, Z. E. Roberto, and H. Del Valle. 2001. Ecological lessons and applications from one century of low external-input farming in the pampas of Argentina. Agriculture, Ecosystems and Environment 83(1-2):65-81.

Viglizzo, E. F., Z. E. Roberto, F. Lértora, E. López Gay, and J. Bernardos. 1997. Climate and landuse change in field-crop ecosystems of Argentina. Agriculture, Ecosystems and Environment $\mathbf{6 6}$ (1):61-70.

Vitousek, P. M. 1994. Beyond global warming: ecology and global change. Ecology $\mathbf{7 5}$ (7):1861-1876. 
Appendix 1. Image processing

Please click here to download file 'appendix1.pdf'. 


\section{Appendix 2. LULC classification evaluations}

\section{Please click here to download file 'appendix2.pdf'.}


Appendix 3. LULC detailed results

Please click here to download file 'appendix3.doc'. 